\title{
Fiscal Federalism at the Ballot Box: The Relevance of Expressive Voting
}

\author{
PHILIP JONES, NILS SOGUEL*
}

University of Bath; IDHEAP - Swiss Graduate School of Public Administration

This paper explores the impact of citizens' motivation to vote on the pattern of fiscal federalism. If the only concern of instrumental citizens was outcome they would bave little incentive to vote because the probability that a single vote might change an electoral outcome is usually minuscule. If voters turn out in large numbers to derive intrinsic value from action, how will these voters choose when considering the role local jurisdictions should play? The first section of the paper assesses the weight that expressive voters attach to an instrumental evaluation of alternative outcomes. Predictions are tested with reference to case study analysis of the way Swiss voters assessed the role their local jurisdiction should play. The relevance of this analysis is also assessed with reference to the choice that voters express when considering other local issues. Textbook analysis of fiscal federalism is premised on the assumption that voters register choice just as 'consumers' reveal demand for services in a market, but how robust is this analogy?

\section{INTRODUCTION}

Government spending and taxation are usually assessed with reference to the preferences of a representative voter and, if communities rely on a simple majority $(50 \%+1)$ voting rule, the representative voter is the median voter. ${ }^{1}$ This textbook approach is applied when assessing the way that voters assign fiscal responsibilities to decentralized jurisdictions (Bradford and Oates, 1971). It is premised on the assumption that voters express choice just as consumers reveal demand. Voters are described as taxpaying-consumers; they reveal

\footnotetext{
* This is a revised version of a paper presented at the Conference, "Ex Uno Plures, Welfare Without Illusion," Sapienza University of Rome, September 2009. The authors would like to acknowledge helpful comments from participants at the Conference. If there are errors, they are the sole responsibility of the authors.

1 The preferences of the median voter are analyzed to predict the outcome of an election if preferences are single-peaked and issues are uni-dimensional.
} 
choice in a "political market" (Peacock, 1992:49-58). How helpful is this analogy when studying fiscal federalism?

Instrumental citizens (focused on outcome) have little incentive to vote when the probability that a single vote will change an electoral outcome is minuscule (Mueller, 2003). A growing empirical literature explains high turnout rates with reference to the intrinsic value voters derive from the act of voting. The architects of utility theory (e.g. Bentham, 1789) recognized that individuals derive value from action as well as from outcome contingent on action but, as theory evolved, attention came to focus on 'outcome' (Loewenstein, 1999). What if voters are also "...intrinsically motivated to perform an activity when one receives no apparent reward except the activity itself..." (Deci, 1971:105)?

Voters might derive intrinsic value from action in many ways but, as this paper considers choice, the focus is on intrinsic value derived by expressing choice (see Jones and Dawson, 2008). Textbooks assume that voters assess the assignment of fiscal responsibilities with reference to outcome. The expectation is that voters will assess the benefits they are likely to experience if services more closely match local preferences and the costs they might incur if they lose economies of scale (Oates, 1972). ${ }^{2}$ But what if citizens also derive intrinsic value when they express identity with their local community?

Section 2 of the paper focuses on voters' preferences for the assignment of fiscal responsibility to a local community. Predictions are tested with reference to a case study of Swiss voters but, as case studies are seldom sufficient to sustain general conclusions, later sections of the paper consider the ways that the theory of expressive voting might also explain other choices registered at the ballot box. With a growing empirical literature that emphasizes voters' motivation to express identity, how relevant are expressions of identity when analyzing patterns of fiscal federalism?

\section{CHOICE AT THE BALLOT BOX}

Instrumental citizens consider the benefit $(\mathrm{X})$ that is derived from one electoral outcome rather than another. If the probability that a voter might influence an electoral outcome is $\mathrm{p}$, the expected utility from voting is $\mathrm{pX}$. Citizens incur transactions costs of voting $(\mathrm{T})$ when they gather information and register their vote. Instrumental citizens vote if net expected utility $(\mathrm{NEU})$ is positive:

$$
\mathrm{NEU}=\mathrm{pX}-\mathrm{T}>0 .
$$

\footnotetext{
2 As noted in Gruber (2007), this assessment is often augmented with consideration of the spillovers citizens may enjoy from taxpayers in other local jurisdictions.
}

Review of Law \& Economics, () 2010 by bepress 
Fiscal Federalism at the Ballot Box / 471

If the probability that one vote will change an electoral outcome is minuscule, the net expected utility from voting is likely to be negative (Downs, 1957), but citizens turn out to vote in large numbers nonetheless (Aldrich, 1997). The 'paradox of voting' can be explained with reference to intrinsic motivation. Riker and Ordeshook (1968) and Ashenfelter and Kelly (1975) argue that citizens derive intrinsic value when they fulfill civic duty. ${ }^{3}$ Fiorina (1976) and Brennan and Lomasky (1993) argue that individuals derive intrinsic value by expressing their preference in collective decision-making processes.

Aldrich (1997:385) distinguishes between intrinsic value derived by fulfilling civic duty and by "expressing ...preferences" but, in essence, there is a common theme. Citizens vote to express identity with the community and with policies that affect the community. Choice is a signal of self-image - to voters themselves in secret ballots, and to others in open ballots and when voters report their electoral identity. ${ }^{4}$

Akerlof and Kranton survey an empirical literature that emphasizes the importance of identity. They conclude that ".... person's identity describes gains and losses in utility from behavior that conforms or departs from the norms for particular social categories in particular situations" (2005:12). Wallis (2003:227) argues that individuals "...define who they are in terms of the people they interact with and how they interact" and that individuals also take action to affirm identity even when identity is pre-ordained (by race or by nationality, etc.). Copeland and Laband (2002) report a strong correlation between the decision to vote and 'political expressiveness' (e.g. wearing campaign buttons, posting political signs and contributions via income tax returns).

If individuals derive intrinsic value from expressive action (E), they will vote if:

$$
\mathrm{NEU}=\mathrm{pX}+\mathrm{E}-\mathrm{T}>0
$$

Some suggest that E only depends on turning out to vote and that, having turned out to vote, citizens register choice instrumentally. Brennan and Lomasky (1985:194) argue that this implies “...motivational schizophrenia” and Elster (1986:26) comments:

\footnotetext{
${ }^{3}$ Downs referred to civic duty by arguing that instrumental citizens vote because otherwise democracy will not survive. But this implies that they would vote to promote a public good; instrumental voters would not incur these costs (Aldrich, 1997). This paper focuses on intrinsic motivation.

${ }^{4}$ Citizens derive intrinsic value by expressing self-image at the ballot box in secret ballots and later - for as Hamlin and Jennings (2009:12) argue: "I can surely hold that I wish to express my political views in all sorts of public...arenas, and the only way in which I can make these expressions in future while maintaining a degree of internal consistency and integrity is to vote expressively."
}

http://www.bepress.com/rle/vol6/iss3/art8

DOI: 10.2202/1555-5879.1536 
"...to explain that people vote, an appeal to civic duty or similar normative concepts seems inevitable; to explain how they vote, the appeal to self-interest is usually deemed sufficient (Barry, 1978). It is as if the voter, upon entering the voting booth, sheds the social motivations that had carried him there. Surely, this cannot be the right conceptualisation -but what is?" (author's emphasis).

The decision of whether to vote is important when considering how to vote (e.g. Jones and Dawson, 2007). Citizens derive intrinsic value from the way they act and there are strong incentives at the ballot box to act expressively.

To illustrate, compare the choice an individual makes as a consumer and the choice that the same citizen would make as a voter:

(i) A citizen chooses between a small-engine motor car and a large-engine motor car. If choice were solely instrumental, the citizen would prefer the large-engine motor car. However, as a consumer the individual is also able to derive intrinsic value by expressing identity with the community (E) and by choosing the small-engine motor car (the large-engine model would increase pollution costs for the community). ${ }^{5}$ The 'price' of choosing the small-engine motor car is the net utility that would have been derived from the large-engine motor car. This depends on the cost (C) of loss of additional (instrumental) utility that would have been derived by consuming the large-engine motor car, net of the cost-saving experienced by choosing the small-engine motor car (B). The 'price' of expressive action is $(\mathrm{C}-\mathrm{B})$. The consumer chooses the smallengine car if $\mathrm{E}>(\mathrm{C}-\mathrm{B})$.

(ii) At the ballot box, the same citizen is now asked to approve legislation to ban large-engine motor cars. The net cost to the citizen (in terms of loss of the large-engine motor car) is $(\mathrm{C}-\mathrm{B})$, but the weight that the citizen gives to $(\mathrm{C}-\mathrm{B})$ is quite different. The 'price' of expressive action is lower. The price is $\mathrm{p}$ (the probability that a vote will prove significant in decision-making) multiplied by the net instrumental utility that the consumer would derive from a large-engine motor car. The 'price' of voting to ban large engine motor cars is $\mathrm{p}(\mathrm{C}-\mathrm{B})$. The same citizen is far more likely to choose expressively (to approve the legislation) because the price is only $\mathrm{p}(\mathrm{C}-\mathrm{B}) . \mathrm{Ex}$ ante each voter's incentive is

\footnotetext{
${ }^{5}$ Consumers pay more for 'eco-labelled' products to express environmental concern (Zarrilli et al., 1997). Investors choose lower-yielding ethical investment to identify with preferred production processes (Lewis et al., 1998).
}

Review of Law \& Economics, ( 92010 by bepress 
Fiscal Federalism at the Ballot Box / 473

to act expressively but, if all act this way, expost each voter experiences the cost $(\mathrm{C}-\mathrm{B})$. The voter approves the legislation if $\mathrm{E}>\mathrm{p}(\mathrm{C}-\mathrm{B}){ }^{6}$

How does this distinction apply when considering preferences for the decentralized provision of local services? The first question considered is how does expressive voting affect the way that individuals vote to assign fiscal responsibilities to their local jurisdiction. The individual considers the extent to which the provision of local services (primary education, street lighting and refuse collection) should be the responsibility of the local jurisdiction. Therefore 'quantity' in Figure 1 refers to the number of services that the voter considers the prerogative of the local community.

When voting for local control, the voter derives diminishing marginal intrinsic value (E) by identifying with the local community (i.e. by calling for greater local provision of services). The 'price' of expressive action is the cost that will be incurred (by increasing local authority provision of services). The voter experiences additional tax cost $(\mathrm{C})$ by rejecting the cost savings that would be possible (from economies of scale) if service provision were the responsibility of a larger jurisdiction. If the individual gains B because there is a better match between service provision and local preferences, the cost in calling for local autonomy is $(\mathrm{C}-\mathrm{B}) .^{7}$

If each local voter chooses as a 'taxpaying-consumer,' each individual chooses $\mathrm{q}_{1}$ services to assign to the local community. But, if each citizen recognizes that a single vote has very little impact on outcome, the 'price' of expressive action is only $\mathrm{p}(\mathrm{C}-\mathrm{B})$ and each citizen prefers that $\mathrm{q}_{2}$ services are provided locally. Even though voters derive intrinsic value (E) from expressive action, devolution of fiscal responsibility to the local community is 'excessive' (the costs equal $\Delta 123$ in Figure 1).

Later sections of the paper focus on how an individual chooses the 'quantity' of a good such as education (and the comparison is between $\mathrm{q}_{0}$ and $\mathrm{q}_{2}$ ). Here the comparison is between $\mathrm{q}_{1}$ and $\mathrm{q}_{2}$ and 'quantity' refers to the number of services citizens would devolve to their local jurisdiction. The next section tests the proposition that they prefer greater devolution when they choose as voters (rather than as consumer-taxpayers).

\footnotetext{
${ }^{6}$ Even if satisfaction from expressive approval (E) differed in the two examples (in one case it is by voting and in the other by purchasing), it remains the case that 'choice' depends on the 'price' of expressive approval (as experienced in each forum).

7 The cost might increase as more services are assigned to the local community, but to ease exposition $(\mathrm{C}-\mathrm{B})$ is constant in Figure 1.
}

http://www.bepress.com/rle/vol6/iss3/art8

DOI: $10.2202 / 1555-5879.1536$ 


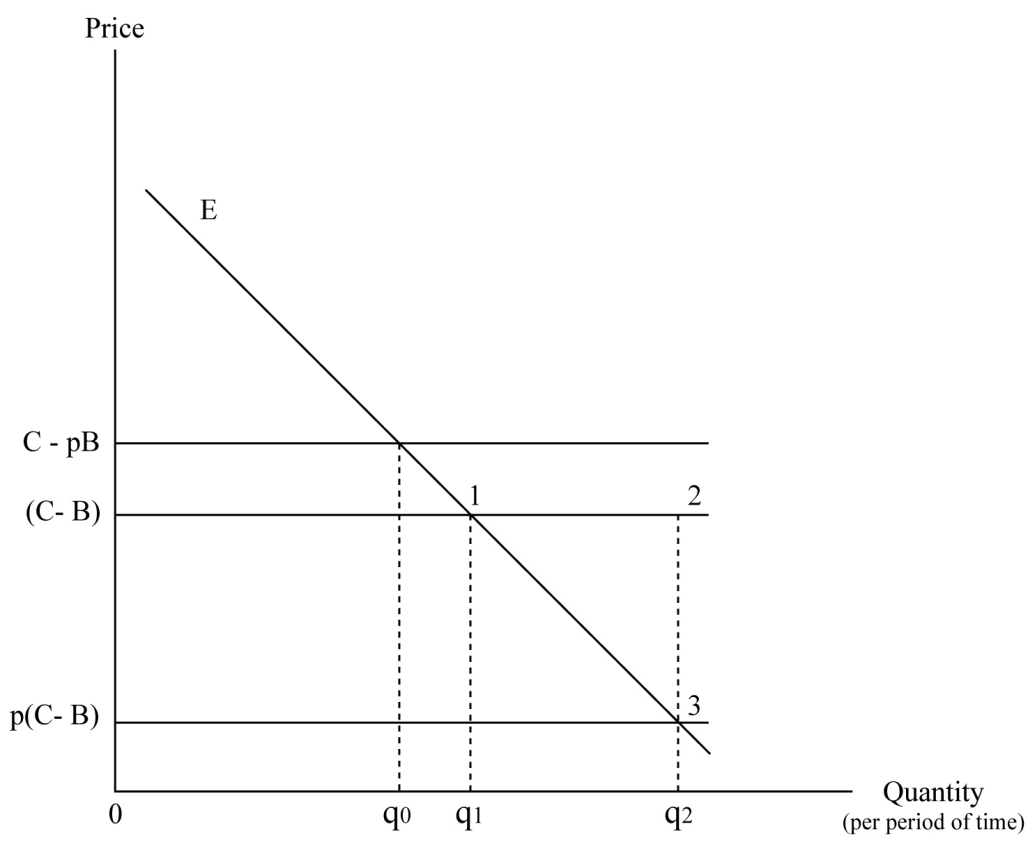

Figure 1. Expressive Voting

A plethora of empirical studies indicate that voters choose expressively. Voters rely more heavily on symbols than on 'pocket book' evaluation (e.g. Sears et al., 1980). Voters are more likely to support collective provision of services the more they choose to participate in collective decision-making (Pommerehne et al., 1997; Jones and Dawson, 2008). But is this theory relevant when analyzing patterns of fiscal federalism?

\section{DEVOLVING FISCAL RESPONSIBILITY: A CASE STUDY}

The Swiss villages of Corcelles-Cormondrèche (hereafter Corcelles, about 4400 inhabitants) and Peseux (about 5600 inhabitants) are neighbors in the conurbation of the small town of Neuchâtel (about 32,400 inhabitants). In June 2003 residents in these local jurisdictions received a questionnaire. The questionnaire asked:

"Would you agree that cooperation between Corcelles-Cormondrèche and Peseux should be strengthened?"

Review of Law \& Economics, (c) 2010 by bepress 
Fiscal Federalism at the Ballot Box / 475

If respondents answered 'yes,' they were then asked whether cooperation should take the form of: (i) restricted and specific cooperation (for confined public services only); (ii) systematic cooperation (for clusters of public services), or (iii) amalgamation (a new single municipality with a single municipal legislature and a single executive). Replies were anonymous. ${ }^{8}$

With reference to the discussion in section 2 of this paper, the important observation is that the questionnaire implicitly directed respondents to consider issues instrumentally. As citizens later expressed choice at the ballot box, it is possible to test the proposition that the incentive to vote expressively is relevant.

Respondents to questionnaires were directed to consider a list of 'key issues' that focused on outcome (Keating, 1995). ${ }^{9}$ They were asked whether they had 'hopes' or 'fears' (just as decision-makers are sometimes asked if they see change as a 'strength,' 'weakness,' 'opportunity' or 'threat' in a SWOT analysis). They were directed to focus on:

(i) Tax: citizens might hope for cost savings (from economies of scale), but be fearful if there was an absence of competition. ${ }^{10}$

(ii) Services: citizens might fear they would lose the match between service provision and local preferences (Oates, 1972; Gassmann, 1993; Vojnovic, 2000), but hope for economies of scope (Steiner, 2003:556).

(iii) Development: citizens might hope for gains derived by pooling resources (Swianiewicz, 2002:10; Thiessen, 2004).

\footnotetext{
8 Citizens were informed that there would be a lottery draw with a prize randomly awarded to two respondents. The questionnaire was introduced by a personal letter, addressed and signed by the President of the municipality (the Mayor).

${ }^{9}$ Keating (1995) reviews the arguments of supporters and opponents of consolidated local government according to four great issues: efficiency, democracy, distribution and development. The spectrum of concerns presented to respondents put aside the issue of distribution since upper tiers rather than municipalities are responsible for such policies.

${ }_{10}$ An empirical literature already highlights sensitivity to tax. This is often evident for highincome citizens. Leuenberger's (1999) exit poll of voters in the Swiss municipality of Jona indicated that the main reason why voters rejected the proposal to amalgamate with the municipality of Rapperswil was that they did not believe the government's promise that taxes would not increase as a consequence (Jona was the wealthiest of the two jurisdictions and the one with the lowest tax rates). Filer and Kenny (1980) referred to the same consideration when analyzing 52 city-county consolidations between 1949 and 1976 in the United States. They reported greater 'fear' the wider the gap between median incomes in the two jurisdictions. Brink (2004) drew attention to preference for secession by voters in the more wealthy municipalities when studying the break-up of Swedish municipalities.
}

http://www.bepress.com/rle/vol6/iss3/art8

DOI: 10.2202/1555-5879.1536 
(iv) Politics: citizens might hope for more competition between local politicians responsible for providing services (Dafflon, 1998:140; Steiner, 2003:556).

(v) Power: citizens might hope that collaboration would increase their bargaining power (with other municipalities and with central government).

(vi) Control: citizens might fear that they would lose control of local government as the size of the jurisdiction increased (Poel, 2000; OECD, 2005).

(vii) Identity: if citizens 'consumed' a bond with their jurisdiction's armorial bearing (Kushner \& Siegel, 2003), they might fear the loss of this affiliation. The expectation was that citizens in Corcelles would experience a closer bond. Corcelles, $30 \%$ smaller than Peseux, lies further west (next to Peseux, but not abutting Neuchâtel). Peseux is geographically closer to the town of Neuchâtel (lying right to the west of it).

Questionnaire respondents were asked to consider pros and cons that related to outcome. ${ }^{11}$ Their responses can be compared with the choice citizens expressed at the ballot box, but the first objective is to show that their questionnaire response was instrumental. Questionnaire responses appeared instrumental because:

(i) If questionnaire responses were instrumental, tax and local service provision were likely to prove more salient than other considerations: As in Figure 1, these considerations are more likely to resonate with consumers. Consideration of other 'key issues' (i.e. development, politics, power and control) are less likely to resonate because they assume the properties of public goods.

An analysis of response indicates that tax cost and service provision were the most salient issues. Table 1 reveals that this concern was mentioned by approximately $40 \%$ of respondents in both municipalities as a hope (column "hopes only"). When considering their overall importance (i.e. inclusive of their importance to voters who still found it difficult to discern whether they constituted a hope or a fear) they were dominant (e.g. as a potential 'hope' they were cited by $86 \%$ of respondents in Corcelles and by $89 \%$ of voters in Peseux).

\footnotetext{
11 The 'key issues' were presented to all respondents in the following order: 'development,' 'services,' 'tax/cost,' 'power,' 'control,' 'identity,' and 'politics.'
}

Review of Law \& Economics, () 2010 by bepress 
Fiscal Federalism at the Ballot Box / 477

Table 1. Hopes and Fears of Closer Cooperation (\%)

\begin{tabular}{|c|c|c|c|c|c|c|c|c|c|c|}
\hline & \multicolumn{2}{|c|}{ Hopes only } & \multicolumn{2}{|c|}{ Fears only } & \multicolumn{2}{|c|}{$\begin{array}{c}\text { Hopes } \\
\text { and fears }\end{array}$} & \multicolumn{2}{|c|}{ Hopes } & \multicolumn{2}{|c|}{ Fears } \\
\hline & Corc. & Pes. & Corc. & Pes. & Corc. & $\overline{\text { Pes. }}$ & Corc. & Pes. & Corc. & Pes. \\
\hline & $a$ & $\mathrm{~b}$ & $\mathrm{C}$ & $\bar{d}$ & $\mathrm{e}$ & $\bar{f}$ & $a+e$ & $b+f$ & $\mathrm{c}+\mathrm{e}$ & $d+f$ \\
\hline Tax/Cost & 37.8 & 39.1 & 8.2 & 5.2 & 48.1 & 49.7 & 86.0 & 88.8 & 56.3 & 55.0 \\
\hline Services & 37.8 & 39.1 & 8.2 & 5.2 & 48.1 & 49.7 & 86.0 & 88.8 & 56.3 & 55.0 \\
\hline Development & 39.9 & 39.1 & 10.8 & 10.3 & 13.8 & 17.0 & 53.8 & 56.1 & 24.7 & 27.3 \\
\hline Politics & 7.2 & 7.7 & 29.7 & 26.4 & 3.7 & 4.0 & 10.9 & 11.7 & 33.4 & 30.4 \\
\hline Power & 40.6 & 34.1 & 7.1 & 7.0 & 6.3 & 7.2 & 46.9 & 41.3 & 13.4 & 14.2 \\
\hline Control & 40.6 & 34.1 & 7.1 & 7.0 & 6.3 & 7.2 & 46.9 & 41.3 & 13.4 & 14.2 \\
\hline Identity & 4.3 & 7.7 & 44.3 & 35.8 & 5.4 & 3.6 & 9.6 & 11.3 & 49.7 & 39.4 \\
\hline
\end{tabular}

(ii) If questionnaire responses were instrumental, citizens in the smaller community were likely to have more to fear from collaboration: Following Tullock (1959), theory predicts that minorities are vulnerable to the costs that are imposed by majorities if communities rely on a simple majority voting rule $(50 \%+1)$. If individuals considered collaboration instrumentally, the prediction is that residents in a smaller jurisdiction would be more likely to resist collaboration.

To test the proposition that residents in the smaller jurisdiction would have more to fear, Table 2 presents the results of a logit analysis of respondents' decisions to accept (or reject) amalgamation. The explanatory variables are the concerns that respondents quote (a specific hope or fear is set as $1 ; 0$ ). Marginal effects estimate the impact of each item on the likelihood that someone would agree to amalgamation. They reveal the 'key issues' that exerted the largest impact on willingness to accept amalgamation and they show the relative importance of the 'key issues' in the two jurisdictions.

As anticipated, all 'hopes' (premised on instrumental cost, $\mathrm{C}$, and instrumental benefit, B) affect positively the likelihood that someone might agree to amalgamation, whereas all 'fears' affect decisions negatively. ${ }^{12}$ However, with reference to predictions premised on the size of jurisdiction, fear about future tax costs was more relevant (i.e. more negative) for citizens in Corcelles and less relevant for citizens in Peseux who would constitute the new majority. ${ }^{13}$

12 In Table 2 the percentage of correctly predicted outcomes is slightly higher for the respondents of Corcelles (76\%), and so is the McFadden's $\mathrm{R}^{2}$. The predicted value that the average respondent considers amalgamation as the most appropriate form of cooperation is $25 \%$ in Corcelles and $46 \%$ in Peseux, quite close to the result of the survey $(23 \%$ and $43 \%)$.

${ }^{13}$ To some extent this fear might also have reflected the observation that residents of Corcelles paid a local tax equivalent to $89.4 \%$ of the tax they paid to the upper-canton-tier, but those in Peseux paid $94.0 \%$.

http://www.bepress.com/rle/vol6/iss3/art8

DOI: $10.2202 / 1555-5879.1536$ 
Table 2. A Logit Model of Respondents' Assessment of Amalgamation a

\begin{tabular}{|c|c|c|c|c|c|c|}
\hline & \multicolumn{3}{|c|}{ Corcelles } & \multicolumn{3}{|c|}{ Peseux } \\
\hline & Coef & z stat $^{b}$ & Marg.effect $^{c}$ & Coef & z stat $^{b}$ & Marg.effect $^{c}$ \\
\hline \multicolumn{7}{|l|}{ Hopes } \\
\hline H_Tax/Cost & $0.7669^{* *}$ & 2.78 & 0.1240 & $0.5863^{* *}$ & 2.63 & 0.1403 \\
\hline H_Services & $0.4586^{*}$ & 2.28 & 0.0849 & 0.3226 * & 2.00 & 0.0798 \\
\hline H_Development & $0.7420^{\star \star}$ & 3.96 & 0.1367 & $0.7086^{\star \star}$ & 4.45 & 0.1735 \\
\hline H_Politics & 0.3469 & 1.29 & 0.0696 & 0.4349 * & 2.02 & 0.1083 \\
\hline H_Power & $0.4781^{*}$ & 2.44 & 0.0905 & $0.3971^{*}$ & 2.46 & 0.0986 \\
\hline H_Control & 0.4776 & 1.68 & 0.0981 & $0.6765^{* *}$ & 3.23 & 0.1672 \\
\hline H Identity & 0.1624 & 0.53 & 0.0316 & 0.1416 & 0.65 & 0.0353 \\
\hline \multicolumn{7}{|l|}{ Fears } \\
\hline F_Tax/Cost & $-0.9407^{* *}$ & -5.39 & -0.1820 & -0.1161 & -0.87 & -0.0289 \\
\hline F_Services & $-0.4120^{*}$ & -2.38 & -0.0759 & $-0.3537^{*}$ & -2.55 & -0.0873 \\
\hline F_Development & -0.2522 & -1.29 & -0.0460 & $-0.3698^{*}$ & -2.47 & -0.0909 \\
\hline F_Politics & $-0.8329^{* *}$ & -4.49 & -0.1462 & $-0.3762^{* *}$ & -2.67 & -0.0926 \\
\hline F_Power & $-0.8019^{* *}$ & -3.21 & -0.1288 & $-0.3563^{*}$ & -2.03 & -0.0871 \\
\hline F_Control & $-0.5503^{* *}$ & -3.16 & -0.0996 & $-0.3695^{* \star}$ & -2.72 & -0.0910 \\
\hline F Identity & $-0.6772^{\star *}$ & -3.91 & -0.1278 & $-0.3325^{*}$ & -2.46 & -0.0822 \\
\hline constant & -1.0630 * & -2.32 & & $-0.8916 *$ & -2.42 & \\
\hline $\bar{N}$ & 951 & & & 1159 & & \\
\hline McFadden's $\mathrm{R}^{2}$ & 0.0839 & & & 0.0322 & & \\
\hline Correctly predicted & $75.81 \%$ & & & $58.58 \%$ & & \\
\hline Predicted value & 0.25206 & & & 0.46156 & & \\
\hline
\end{tabular}

a. Dependent variable is the acceptance $(=1)$, or rejection $(=0)$ of an amalgamation.

b. $*$, ** denotes significance at the $5 \%$ or $1 \%$ respectively (two-tailed).

c. Since all explanatory variables are dummy variables, the marginal effect is when the value flips

from 0 to 1 ; it is estimated at the means of the independent variables.

(iii) If responses were instrumental, citizens in the smaller jurisdiction would be more likely to resist their loss of a bond with their local community. The consumption value of a bond is quite different to the intrinsic value that is derived from action expressing identity. The consumption value of the bond depends on outcome (rather than action). An individual may consume a bond without any expressive action.

Studies on social identity suggest that such a bond is stronger in smaller communities. ${ }^{14}$ The prediction is that instrumental citizens are more likely to 'fear' this loss in the smaller community. Table 1 indicates that the bond was important for all citizens (a result that proves consistent with evidence in other studies of Swiss decentralization, e.g. Steiner (2003)) but that fear of losing this bond was stronger in the smaller jurisdiction (Corcelles).

14 Analysis of social identity theory often focuses on group size. Liebkind et al. (2008:636) consider the literature that relies on group size to explain 'intergroup bias' (defined as a "...systematic tendency to evaluate the in-group and its members more favourably than the outgroup and its members").

Review of Law \& Economics, ( 2010 by bepress 
Fiscal Federalism at the Ballot Box / 479

When considering all of these issues, citizens in the larger jurisdiction were more positive. $91 \%$ of respondents in the larger jurisdiction (Peseux) were prepared to consider closer cooperation but only $82 \%$ were prepared to consider closer cooperation in the smaller jurisdiction (Corcelles). Now the question is whether choice differed systematically at the ballot box.

The analysis presented in Figure 1 predicts that:

- voters will systematically discount instrumental evaluation by expressing identity with local provision of services

- voters in the large jurisdiction are more likely to resist collaboration, because in the larger jurisdiction (where $p$ is lower) there is an even greater incentive to discount instrumental evaluation.

On 9 December 2007 citizens voted in a referendum. They were asked whether they were prepared to accept amalgamation between the two jurisdictions. In the questionnaire only $23 \%$ of citizens in Corcelles approved amalgamation as compared with $42 \%$ in the larger jurisdiction of Peseux. But if expressive voting theory were relevant, voters in the larger jurisdiction (Peseux) would be less willing to amalgamate (because $\mathrm{p}$ is lower and there is greater incentive to discount instrumental evaluation to vote expressively).

Table 3 compares the results of the questionnaire and the referendum. At the ballot box, $59 \%$ of voters in Corcelles approved amalgamation but only $43 \%$ of voters approved amalgamation in the larger jurisdiction (Peseux). As predicted (with reference to Figure 1), voters in the larger jurisdiction attached greater weight to expressions of identity and were less willing to relinquish support for devolved provision of services. ${ }^{15}$

\footnotetext{
15 The law required that a majority of the voters accept the proposal in each municipality and the two municipalities did not amalgamate.

http://www.bepress.com/rle/vol6/iss3/art8

DOI: $10.2202 / 1555-5879.1536$
} 
Table 3. A Comparison of Survey and Referendum Results

\begin{tabular}{|c|c|c|}
\hline & Corcelles & Peseux \\
\hline \multicolumn{3}{|l|}{ 2003-survey outline } \\
\hline Number of inhabitants (2003) & 4074 & 5594 \\
\hline Number of registered voters (2003) and distributed questionnaires & 3055 & 4211 \\
\hline Number of returned questionnaires & 1274 & 1471 \\
\hline Response rate & $42 \%$ & $35 \%$ \\
\hline Respondant who would agree to strenghten the cooperation & $82 \%$ & $91 \%$ \\
\hline \multicolumn{3}{|l|}{ Agreement to a given form of cooperation } \\
\hline No Cooperation & $5 \%$ & $5 \%$ \\
\hline Restricted and Specific Cooperation & $65 \%$ & $59 \%$ \\
\hline Systematic Cooperation & $40 \%$ & $47 \%$ \\
\hline Amalgamation & $23 \%$ & $42 \%$ \\
\hline \multicolumn{3}{|l|}{ 2007-referendum outcome } \\
\hline Number of inhabitants (2007) & 4405 & 5648 \\
\hline Number of registered voters (2007) & 3293 & 4179 \\
\hline Number of voters who show to the polls & 2038 & 1937 \\
\hline Turnout rate & $62 \%$ & $46 \%$ \\
\hline \multicolumn{3}{|l|}{ Number of voters who ... } \\
\hline ... accept the amalgamation & 1202 & 837 \\
\hline ... reject the amalgamation & 836 & 1100 \\
\hline Rate of acceptance & $59 \%$ & $43 \%$ \\
\hline
\end{tabular}

There are always qualifications when focusing on a single case study. It is always difficult to impute motivation from behavior. While it is impossible to ask individuals to consider the same question instrumentally and expressively at the same moment of time, it is impossible to dismiss the possibility that preferences change over time. Of course, in this context, it is important to note that the evidence suggests that it is the strength of intrinsic motivation that systematically atrophies over time (and, in this case, the observation that expressive voting is still relevant highlights the importance of incentives at the ballot box). ${ }^{16}$ Also questionnaire studies are inevitably sensitive to the criticism that responses depend on the way questions are asked and this study is no exception. ${ }^{17}$

Yet, for all of these qualifications, results are consistent with the proposition that choice depends on the forum in which individuals express choice. If

16 The evidence is that intrinsic motivation is 'crowded out' the longer the time span over which individuals assess costs and benefits (Frey et al., 1996).

17 It is difficult to make direct comparisons between 'support for amalgamation by questionnaire respondents' and 'electoral support for amalgamation.' Questionnaire respondents were offered a menu of co-operative possibilities. Also, the comparison is between the sample of questionnaire responses and responses at the ballot box (rather than between the response that each individual made in a survey and at the ballot box).

Review of Law \& Economics, ( 2010 by bepress 
Fiscal Federalism at the Ballot Box / 481

patterns of fiscal federalism depend on voters' preferences, patterns of fiscal responsibility differ systematically from patterns predicted with reference to Oates' (1972) instrumental comparison of costs and benefits.

\section{THE RELEVANCE OF CASE STUDIES}

One way of assessing the significance of this case study is to consider whether the same interpretation proves relevant when considering other fiscal federalism issues. In this section of the paper q (in Figure 1) refers to the provision of a specific local service. The question is whether choice at the ballot box is still sensitive to the incentive to vote expressively.

\subsection{THE PROVISION OF WELFARE SERVICES}

The importance of the forum in which choice is expressed can be highlighted by considering provision of a collective good. In a large group an instrumental citizen would attempt to 'free ride' rather than contribute voluntarily to the provision of a collective good (Buchanan, 1968). An individual who derives intrinsic value from expression of identity (by contributing to a collective good) might contribute if $\mathrm{E}$ exceeds the cost of contribution (C) minus the expected benefit $(\mathrm{pB})$ of the contribution (when $\mathrm{p}$ is the probability that a single donation will prove effective in supplying the collective good). In Figure 1 the price of a voluntary contribution is $\mathrm{C}-\mathrm{pB}$.

If the same citizen is asked to contribute to provision of a collective good via a tax-financed program, the 'price' of expressive voting is $\mathrm{p}(\mathrm{C}-\mathrm{B})$ when, in this case, $\mathrm{p}$ is the probability that a single vote will be effective. If, in each instance, the values of $\mathrm{C}$ and $\mathrm{B}$ are identical and, if the probability that a single vote will be effective equals the probability that a contribution to a collective good will be significant (both approaching zero), the same individual will approve greater provision of a collective good at the ballot box. In Figure 1 the citizen voluntarily contributes to provide $\mathrm{q}_{0}$ units, but votes for $\mathrm{q}_{2}$ units if there is a tax-financed program.

It is possible to analyze altruism as the provision of a collective good (Hochman and Rodgers, 1969). If citizens consider contributing in order to altruistically provide a welfare service, the prediction is that there will be greater provision at the ballot box, and that provision will be greater the lower the perception that a single vote is significant. Sobel and Wagner (2004) tested this proposition with reference to the significance of a single vote in 49 states in the USA between 1972 and 1996. They concluded that "...the probability of casting the decisive vote is an important determinant of welfare spending..." and that "...a ten percent

http://www.bepress.com/rle/vol6/iss3/art8

DOI: $10.2202 / 1555-5879.1536$ 
reduction in the probability of casting the decisive vote generally leads to approximately a 6 per cent increase in public welfare spending..." (2004:151).

The evidence is consistent with the proposition that fiscal federalism is sensitive to the incentives that voters face at the ballot box. ${ }^{18}$

\subsection{THE 'FLYPAPER EFFECT'}

The argument that individuals attach greater importance to expressive action at the ballot box is relevant when considering the 'flypaper effect.' If local voters expressed 'demand' instrumentally, their response to an increase in private income would be the same as their response to receipt of an unconditional lump sum grant from the federal government. The evidence is that voters prefer to increase local services by between 5 and 10 cents when private income increases by $\$ 1$, but by between 40 cents and $\$ 1$ when they are in receipt of a $\$ 1$ unconditional lump sum grant. Hines and Thaler (1995) refer to Arthur Okun's description of this as the 'flypaper effect' ('money sticks where it hits').

Arguments based on instrumental rationality (see Bailey and Connolly, 1998) fail to explain the flypaper effect (see Hines and Thaler's 1995 critique). Analysis based on expressive action offers a different approach. ${ }^{19}$ Individuals' perceptions of the intrinsic value of action depend on moral considerations and on the observation that action is acknowledged (e.g. Deci and Ryan, 1980, 1985; Frey, 1997). When considering the flypaper effect, receipt of a grant is a signal that acknowledges the intrinsic value of support for a local community. Citizens are more likely to vote expressively for greater collective provision (to support the local jurisdiction) if they feel such action is acknowledged.

To illustrate, consider the median voter's preferences in Figure 2(a). They are represented by $I_{1}$ and $I_{2}$ (preferences are homothetic to the origin and the income consumption curve is ICC). The initial budget is 1-2. This representative voter chooses $g_{1}$ of a local service $(\mathrm{G})$. When private income increases, the budget line shifts to 3-4. Now the voter prefers $g_{2}$ (there is a relatively small income effect $\left.\mathrm{g}_{1}-\mathrm{g}_{2}\right)$. The voter chooses to reduce local taxes from $1-\mathrm{y}_{1}$ to $1-\mathrm{y}_{2}$ (the increase in income 'crowds out' local finance for $\mathrm{g}_{1}-\mathrm{g}_{0}$ units (Knight, 2002)).

\footnotetext{
18 The authors considered Tullock's (1973:23) observation that citizens “....vote charitably and act selfishly...." Welfare provision was analyzed as an altruistic act. As predicted by the relative importance of $\mathrm{C}-\mathrm{pB}$ and $\mathrm{p}(\mathrm{C}-\mathrm{B})$ in Figure 1 , citizens are systematically more altruistic when they vote (see Brennan and Lomasky, 1993; Hudson and Jones, 1994; and Mueller, 2003, for reviews of empirical studies).

${ }^{19}$ Hines and Thaler (1995) explain the flypaper effect with reference to the theory of 'mental accounting' but it is still necessary to explain why choice might differ when spending from different 'accounts.'
}

Review of Law \& Economics, () 2010 by bepress 
Fiscal Federalism at the Ballot Box / 483
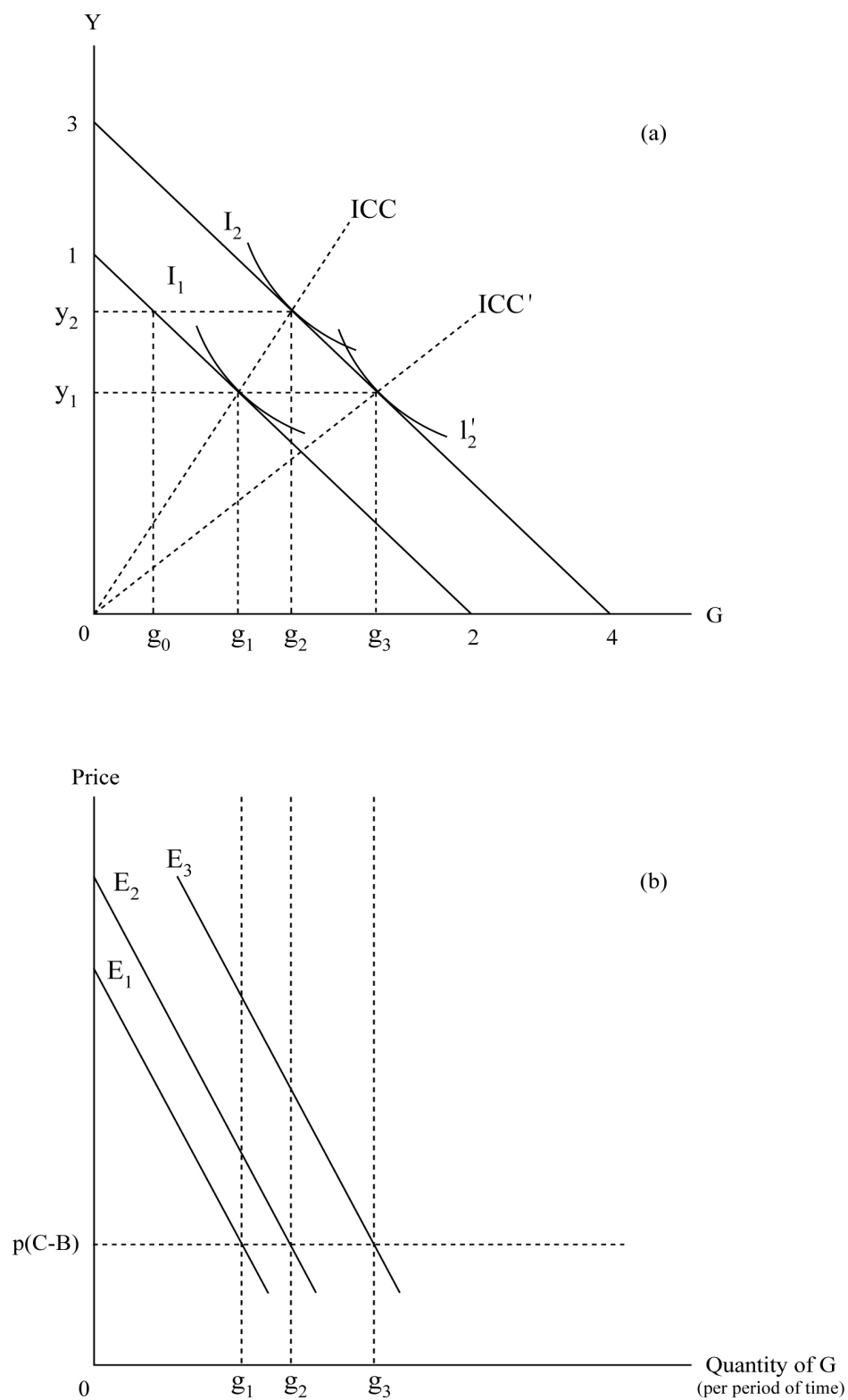

Figure 2. The Flypaper Effect and Crowding Out

http://www.bepress.com/rle/vol6/iss3/art8

DOI: $10.2202 / 1555-5879.1536$ 
The evidence is that crowd-out is far less (and sometimes there is no crowd-out). In Figure 2(a) there is no crowd-out if receipt of an intergovernmental grant acknowledges the intrinsic value of action that supports a local community. ${ }^{20}$ As this signal enhances perceptions of the intrinsic value of identifying with a local community (and this changes the pattern of the indifference curves), the new set of indifference curves (homothetic to the origin, with income consumption curve ICC') are illustrated by $\mathrm{I}_{2}$. In this case, local finance for provision by the local jurisdiction is $1-\mathrm{y}_{1}$ before receipt of the grant and $1-\mathrm{y}_{1}$ after provision of the grant.

When perceptions of the intrinsic value of expressive action depend on signals that acknowledge action, individuals are more willing to vote for spending (because the community is in receipt of a grant). In Figure 2(b) an increase in income shifts $\mathrm{E}$ from $\mathrm{E}_{1}$ to $\mathrm{E}_{2}$ (expressive action is a 'normal' good) but an increase in income received by a local grant shifts $\mathrm{E}$ from $\mathrm{E}_{1}$ to $\mathrm{E}_{3}$.

Once again, the same theory of expressive voting proves relevant when explaining choice at the ballot box.

\section{CONCLUSIONS AND POLICY IMPLICATIONS}

In 1999 Oates reflected on recent developments in the theory of fiscal federalism. He argued that there was "... some interesting work to be done ... exploring... the extent to which people in geographical subareas of a country identify... with that area" (1999:1124). This paper considers the relevance of local identity and the incentive that citizens have to express identity at the ballot box.

Expressive voting is relevant when citizens choose to assign fiscal responsibility. Citizens call for greater local autonomy in the provision of services than would be anticipated with reference to Oates' (1972) analysis of 'optimal' fiscal federalism. A case study of Swiss citizens is consistent with the proposition that choice is sensitive to the forum in which it is expressed. The choice that citizens make as 'consumer taxpayers' differs systematically from the choice they express at the ballot box. While this study adds to a growing empirical literature that highlights the relevance of expressive voting (e.g. Cummings et al., 1997; Carter and Guerette, 1992; Jones and Dawson, 2007), it is the first study to assess the relevance of expressive voting when voters choose to assign fiscal responsibilities to different tiers of government.

Such analysis is important when reflecting on criticisms of the way that fiscal responsibilities have been assigned in the European Union (EU). Mueller (2003)

\footnotetext{
${ }^{20}$ In a different context, Feld and Frey show how potent these signals can be. They refer to a 'psychological contract' (2002:87) between local residents and local authorities.
}

Review of Law \& Economics, (C) 2010 by bepress 
compares the role that the EU budget plays with the role it 'should' play if costs and benefits are assessed instrumentally (as in Oates, 1972). Fewer responsibilities are assigned to the EU than anticipated. Expressive voters are reluctant to transfer fiscal responsibilities to more remote government tiers. The implication is that, if responsibility is to be transferred to the EU budget, citizens must vote as 'European citizens' (rather than as citizens of nation states).

Expressive voting is also relevant when considering the provision of welfare services. Once again, the evidence is consistent with the proposition that electoral choice depends on expressions of identity with local communities. Alesina et al. (1999) show that willingness to provide welfare-state services will increase if citizens are able to identify with others of the same ethnic group (provision is lower if there is ethnic fragmentation in the community). When analyzing local provision of services, expressions of identity are also important. So much so that local provision of welfare services increases as the 'price' of electoral expressions of identity decreases.

The third issue considered in this paper is the observation that expressive voting also proves relevant when explaining the 'flypaper effect.' This behavior is difficult to reconcile with the assumption that voters choose instrumentally (see Cullis and Jones, 2009, for a literature review). By comparison, it is consistent with the observation that citizens vote to express identity with their local community. When the award of an intergovernmental grant acknowledges the value of supporting the local community, citizens respond by approving greater expenditure than predicted (to support the local community).

The arguments in this paper do not depend on the assumption that voters make an accurate assessment of the significance of a single vote or on the assumption that each voter makes the same assessment. Voters may sometimes exaggerate the significance of a single vote. ${ }^{21}$ The arguments depend only on the assumption that voters are more likely to discount the significance of a single vote in a large electorate.

Other explanations have been presented to explain why patterns of fiscal federalism differ systematically from patterns prescribed with reference to Oates' (1972) 'decentralization theorem' (e.g. Hindricks and Myles, 2006), but the distinctive argument in this paper is that these differences depend on citizens' incentive to vote expressively. If analysis of how citizens vote is sensitive to analysis of why citizens vote, choice at the ballot box is likely to be far more expressive than implied by instrumental assessments of the costs and benefits of fiscal federalism.

21 There is evidence that some voters mistakenly exaggerate the significance of their vote (Clarke et al., 2004). Quattrone and Tversky (1986) argue that some voters confuse the causal impact of action with the diagnostic signal (they vote because they know that if sufficient numbers voted for a preferred outcome, this outcome would be achieved, thereby confusing a diagnosis with a causal impact).

http://www.bepress.com/rle/vol6/iss3/art8

DOI: $10.2202 / 1555-5879.1536$ 


\section{References}

Akerlof, G., and G.E. Kranton. 2005. "Identity and the Economics of Organizations," 19 Journal of Economic Perspectives 9-32.

Aldrich, J. 1997. "When is it Rational to Vote" in D.C. Mueller, ed. Perspectives on Public Choice. Cambridge: Cambridge University Press.

Alesina, A., R. Baqir, and W. Easterly. 1999. "Public Goods and Ethnic Divisions," 114 Quarterly Journal of Economics 1243-1284.

Ashenfelter, O., and S. Kelly, Jr. 1975. "Determinants of Participation in Presidential Elections," 18 Journal of Law and Economics 695-733.

Bailey, S.J., and S. Connolly. 1998. "The Flypaper Effect: Identifying Areas for Future Research," 95 Public Choice 335-361.

Barry, B.M. 1978. Economists, Sociologists and Democracy, 3rd edition. Chicago: University of Chicago Press.

Bentham, J. 1789/1948. The Principles of Morals and Legislation. New York: Macmillan.

Bradford, D., and W. Oates 1971. "Towards a Predictive Theory of Intergovernmental Grants," 61 American Economic Review 440-448.

Brennan, G., and L. Lomasky. 1985. “The Impartial Spectator Goes to Washington,” 1 Economics and Philosophy 189-211. and 1993. Democracy and Decision: The Pure Theory of Electoral Preference. Cambridge: Cambridge University Press.

Brink, A. 2004. "The Break-up of Municipalities - Voting Behavior in Local Referenda," 5 Economics of Governance 119-135.

Buchanan, J.M. 1968. The Demand and Supply of Public Goods. Chicago: Rand McNally.

Carter, J.R., and S.D. Guerette. 1992. "An Experimental Study of Expressive Voting," 73 Public Choice 251-260.

Clarke, H.D., D. Sanders, M.C. Stewart, and P.F. Whiteley. 2004. Political Choice in Britain. Oxford: Oxford University Press.

Copeland, C., and D.N. Laband. 2002. "Expressiveness and Voting," 110 Public Choice 351-63.

Cullis, J., and P. Jones. 2009. Public Finance and Public Choice, 3rd edition. Oxford: Oxford University Press.

Cummings, R.G., S. Elliot, G.W. Harrison, and J. Murphy. 1997. “Are Hypothetical Referenda Incentive Compatible?” 105 Journal of Political Economy 609-21.

Carter, J.R., and S.D. Guerette. 1992. "An Experimental Study of Expressive Voting," 73 Public Choice 251-260.

Dafflon, B. 1998. "Suisse: Les Fusions de Communes dans Le Canton de FribourgAnalyse socio-économique," in Annuaire des collectivités locales. Paris: GRALE.

Deci, E.L. 1971. "Effects of Externally Mediated Rewards on Intrinsic Motivation,” 18 Journal of Personality and Social Psychology 105-115. and R.M. Ryan. 1980. "The Empirical Exploration of Intrinsic Motivational Processes" 10 Advances in Experimental Social Psychology 39-80. and 1985. Intrinsic Motivation and Self Determination in Human Behavior. New York: Plenium Press.

Review of Law \& Economics, (C 2010 by bepress 
Fiscal Federalism at the Ballot Box / 487

Downs, A. 1957. An Economic Theory of Democracy. New York: Harper and Row.

Elster, J. 1985. "Rationality, Morality, and Collective Action," 96 Ethics 136-155.

. 1986. The Multiple Self. Cambridge: Cambridge University Press.

Feld, L.P., and B.S. Frey. 2002. "Trust Breeds Trust; How Taxpayers are Treated," 3 Economics of Governance 87-99.

Filer, J.E., and L.W. Kenny. 1980. "Voter Reaction to City-County Consolidation Referenda," 23 Journal of Law and Economics 179-190.

Fiorina, M.P. 1976. "The Voting Decision: Instrumental and Expressive Aspects," 21 Journal of Politics 601-625.

Frey, B.S. 1997. Not Just For the Money: An Economic Theory of Personal Motivation. Cheltenham: Edward Elgar.

F. Oberholzer-Gee, and R. Eichenberger. 1996. "The Old Lady Visits Your Backyard: A Tale of Morals and Markets," 104 Journal of Political Economy 1297-1313.

Gassmann, U. 1993. Kommunale Ausgaben als Ergebnis politisch-ökonomischer Entscheidungsprozesse? Bern: Paul Haupt.

Gruber, J. 2007. Public Finance and Public Policy, 2nd edition. New York: Worth Publishers.

Hamlin, A., and C. Jennings. 2009. "Expressive Political Behaviour: Foundations, Scope and Implications," Discussion Paper 09-18, Department of Economics, University of Strathclyde.

Hindricks, J., and G. Myles. 2006. Intermediate Public Economics. Cambridge, MA: MIT Press.

Hines, J.R., and R.H. Thaler. 1995. "Anomalies: The Flypaper Effect," 9 Journal of Economic Perspectives 217-2276.

Hochman, H.M., and J.D. Rodgers. 1969. "Pareto Optimal Redistribution," 57 American Economic Review 542-57.

Hudson, J., and P. Jones. 1994. "The Importance of the 'Ethical Voter': An Estimate of 'Altruism,'" 10 European Journal of Political Economy 499-509.

Jones, P. 2008. “'Motivation Spillover': Tax Policy Designed to Mobilize Collective Action," 8 Public Finance and Budgeting 204-33. and P. Dawson. 2007. "Instrumental Rationality or Expressive Approval? The Intrinsic Value of Public Choice," 36 Journal of Socio Economics 101-117. and _. 2008. "How Much do Voters Know? An Analysis of Motivation and Political Awareness," 55 Scottish Journal of Political Economy 123-142.

Keating, M. 1995. "Size, Efficiency and Democracy: Consolidation, Fragmentation and Public Choice," in D. Judge, G. Stoker, and H. Wolman, eds. Theories of Urban Politics. Thousand Oaks: Sage Publications.

Knight, B. 2002. "Endogenous Federal Grants and Crowd Out of State Government Spending: Theory and Evidence from the Federal Highway Aid Program," 92 American Economic Review 71-92.

Kushner, J., and D. Siegel. 2003. “Citizens' Attitudes Toward Municipal Amalgamation in Three Ontario Municipalities,” 26 Canadian Journal of Regional Science 49-59.

Leuenberger, P. 1999. Exemplarische Nachanalyse der abgelehnten Fusion der Gemeinden Jona und Rapperswil vom 28 November 1999. Zurich: GfS-Forschungsinstitut.

http://www.bepress.com/rle/vol6/iss3/art8

DOI: $10.2202 / 1555-5879.1536$ 
Lewis, A., P. Webley, A. Winnett, and C. Mackenzie. 1998. "Morals and Markets: Some Theoretical and Policy Implications of Ethical Investing," in P. Taylor-Gooby, ed. Choice and Public Policy: The Limits to Welfare Markets. London: Macmillan.

Liebkind, K., A. Henning-Lindblom, and E. Solheim. 2008. "Group Size, Group Status and Trait Valence as Determinants of Intergroup Bias: Stereotyping in Finland and Sweden," 38 European Journal of Social Psychology 637-51.

Loewenstein, G. 1999. "Because it is There: The Challenge of Mountaineering for Utility Theory," 52 Kyklos 315-344.

Mueller, D. 2003. Public Choice III. Cambridge: Cambridge University Press.

Oates, W.E. 1972. Fiscal Federalism. New York: Harcourt Brace Jovanovich. 1999. "An Essay on Fiscal Federalism," 37 Journal of Economic Literature 1120-1149.

OECD. 2005. Building Competitive Regions: Strategies and Governance. Paris: OECD.

Peacock, A. 1992. Public Choice Analysis in Historical Perspective. Cambridge University Press.

Poel, D.H. 2000. "Amalgamation Perspectives: Citizen Responses to Municipal Consolidation," 23 Canadian Journal of Regional Science 31-48.

Pommerehne, W.W., A. Hart, and L.P. Feld. 1997. "Steuerhinterziehung und ihre Kontrolle in unterschiedlichen politischen Systemen," 14 Homo Oeconomicus 469-487.

Quattrone, G.A., and A. Tversky. 1986. "On Self-Deception and the Voter's Illusion” in J. Elster, ed. The Multiple Self. Cambridge: Cambridge University Press.

Riker, W.H., and P.C. Ordeshook. 1968. "A Theory of the Calculus of Voting," 62 American Political Science Review 25-42.

Sears, D.O., R.R. Lau, T.R. Tyler, and H.M. Allen Jr. 1980. "Self-Interest vs. Symbolic Politics in Policy Attitudes and Presidential Voting," 74 American Political Science Review 670-684.

Sobel, R.S., and G.A. Wagner. 2004. "Expressive Voting and Government Redistribution: Testing Tullock's 'Charity of the Uncharitable,'” 119 Public Choice 143-159.

Steiner, R. 2003. "The Causes, Spread, and Effects of Intermunicipal Cooperation and Municipal Mergers in Switzerland," 5 Public Management Review 551-571.

Swianiewicz, P. 2002. "Size of Local Government, Local Democracy and Efficiency," in P. Swianiewicz, ed. Consolidation or Fragmentation? The Size of Local Governments in Central and Eastern Europe. Budapest: Open Society Institute.

Thiessen, U. 2004. "Fiscal Decentralization and Economic Growth in 'Rich' OECD Countries: Is There an Optimum," 41 Economic Bulletin 175-182.

Tullock, G. 1959. "Some Problems of Majority Voting," 67 Journal of Pol. Economy 571-79. 1973. The Economics of Charity. London: Institute of Economic Affairs.

Veblen, T. 1934. Essays in Our Changing Order. New York: Viking Press.

Vojnovic, I. 2000. "Municipal Consolidation, Regional Planning and Fiscal Accountability: The Recent Experience in Two Maritime Provinces," 23 Canadian Journal of Regional Science 49-72.

Wallis, J.J. 2003. "The Public Promotion of Private Interest (Groups)," in J. Heckelman and D. Coates, eds. Collective Choice Essays in Honor of Mancur Olson. New York: Springer-Verlag.

Zarrilli, S, V. Jha, and R. Vossenaar. 1997. Eco-Labelling and International Trade. London: Macmillan.

Review of Law \& Economics, (C) 2010 by bepress 